\title{
John Hilton, 1805-1878
}

\author{
Richard A. Brand MD
}

Published online: 12 June 2009

(C) The Association of Bone and Joint Surgeons $\mathbb{R} 2009$

\begin{abstract}
This biographical sketch of John Hilton corresponds to the historic text, The Classic: On Rest and Pain: Lecture XIV, available at DOI 10.1007/s11999-009-0928-1.
\end{abstract}

John Hilton was born in Castle Hedingham, Essex, in the southeast part of England September 22, 1805 [4]. (Atkins in his biographical notes of Hilton in a reprinted edition of "On Rest and Pain" from 1950 noted various sources incorrectly stated his birth year as 1804 or 1807 [4].) He entered medical school at Guy's Hospital in 1824 at the age of 19. At the quite young age of 23 , he was appointed Demonstrator in Anatomy in 1828. Hilton was by some considered the greatest anatomist of his time, and was nicknamed "Anatomical John" [2]. At the age of 34 he was appointed Fellow of the Royal Society based largely on his anatomical work, and in particular that related to the laryngeal nerves. A few years later Hilton was elected one of the Charter Fellows of the Royal College of Surgeons (attesting to his surgical expertise, although he retained a focus on anatomy). In 1844 he received the title of assistant surgeon at Guy's Hospital and in 1849 full surgeon [1]. (Atkins notes Hilton may have been prevented from earlier appointment as a full surgeon by his predecessor, Aston Key, who was "a testy, impetuous and difficult colleague..." [4]). Hilton, lacking a cultured upbringing, was "brusque in manner, and looking more like a successful business man than a surgeon" [4]. His manner, however, did not prevent his attainment of the highest of appointments: Hilton was

R. A. Brand $(\square)$

Clinical Orthopaedics and Related Research, 1600 Spruce Street, Philadelphia, PA 19103, USA

e-mail: dick.brand@clinorthop.org appointed anatomist to the Royal College of Surgeons in 1959 , became president of that august body in 1867 , and in 1871 shortly after resigning his post at Guy's was appointed "Surgeon-Extraordinary" to Queen Victoria. Working in the pre-anesthetic, pre-Listerian age of surgery, he was a cautious surgeon, perhaps owing to his nature and also to the suggestion that he was not considered a brilliant technician despite his expertise in anatomic dissections. Yet, he was "a very skilful observer and shrewd clinically, he could interest students in the most mundane topics and always managed to find some point overlooked by others so that he was highly regarded as a consultant" [1].

Hilton was married twice, but "...cannot have been much of a family man despite his two marriages. A man who had written so much without mentioning his wife or his family, without ever having referred to the incidents of home life in illustration of some point in a lecture, cannot have had them much on his mind. We never hear or read of an endearing expression coming from him" [4]. Even his will did not mention his surviving children by name. Hilton was evidently devoted to his profession. He died in 1878 of a carcinoma of the stomach after a prolonged period of suffering.

Between 1860 and 1862 while Professor of Anatomy to the Royal College, he delivered a series of lectures which became the basis for his classic, "On Rest and Pain" (originally published as, "On The Influence of Mechanical and Physiological Rest In The Treatment of Accidents and Surgical Diseases, And The Diagnostic Value of Pain" [3]). We reproduce here a portion of Lecture XIV, on "hipjoint disease." He describes "sympathetic pain" in which "one of the earliest symptoms is remote from the actual seat of mischief." In particular he recognized the importance of knee symptoms in hip disease as a result of the 
innervation supplying both joints. He is perhaps best known for Hilton's Law, stated in an earlier lecture (VII), that "The same trunks of nerves, whose branches supply the groups of muscles moving a joint, furnish also a distribution of nerves to the skin over the insertions of the same muscles; and - what at this moment more especially merits our attention - the interior of the joint receives its nerves from the same source." (Italics are Hilton's.) We hope readers will enjoy reading the remarks of so careful a clinician.

\section{References}

1. John Hilton. Available at: http://www.whonamedit.com/doctor. $\mathrm{cfm} / 2559 . \mathrm{html}$. Accessed May 1, 2009.

2. John Hilton (surgeon). Available at: http://en.wikipedia.org/wiki/ John_Hilton_(surgeon). Accessed May 1, 2009.

3. Hilton J. On The Influence of Mechanical and Physiological Rest in the Treatment of Accidents and Surgical diseases, and the Diagnostic Value of Pain. London, England: Bell and Daldy; 1863.

4. Hilton J. Rest and Pain. 6th ed. Walls EW, Philipp EE, Atkins HJB, eds. Philadelphia, PA: J. B. Lippincott Co; 1950. 